\title{
Abnormalities of growth hormone release in response to human pancreatic growth hormone releasing factor (GRF (1-44)) in acromegaly and hypopituitarism
}

\author{
S M WOOD, J L C CH'NG, E F ADAMS, J D WEBSTER，G F JOPLIN，K MASHITER，S R BLOOM
}

\begin{abstract}
Human pancreatic growth hormone releasing factor (GRF (1-44)) is the parent molecule of several peptides recently extracted from pancreatic tumours associated with acromegaly. A study was conducted to examine its effects on the release of growth hormone in normal volunteers and in patients with hypopituitarism and acromegaly.

GRF (1-44) dose dependently stimulated the release of growth hormone in normal people and produced no appreciable side effect. This response was grossly impaired in patients with hypopituitarism and, although similar to the growth hormone response to hypoglycaemia, was of quicker onset and a more sensitive test of residual growth hormone function. Patients with acromegaly appeared to fall into (a) those with a normal response to GRF, whose growth hormone suppressed significantly with oral glucose, and (b) those who had an exaggerated response to GRF (1-44), whose growth hormone had not suppressed previously after oral glucose.
\end{abstract}

Present methods for testing growth hormone deficiency entail using the insulin stress test, which is time consuming, unpleasant, and sometimes dangerous. A single intravenous injection of GRF now offers the possibility of an easier, safer, and more reliable routine test for growth hormone deficiency. It has the further

Department of Medicine, Hammersmith Hospital, London W12 0HS $S M$ WOOD, BSC, $\mathrm{MB}$, registrar in endocrinology

J L C CH'NG, MRCP, registrar in endocrinology

E F ADAMS, BSC, research officer

J D WEBSTER, BSC, research officer

G F JOPLIN, FRCP, reader in medicine

K MASHITER, PHD, principal biochemist

S R BLOOM, FRCP, professor of endocrinology

Correspondence to: Dr S M Wood, 2nd Floor Francis Fraser Laboratories, Hammersmith Hospital, London W12 0HS. advantage of being free of side effects and readily performed in outpatients. Hence it seems likely to become the standard test and take the place of the insulin stress test.

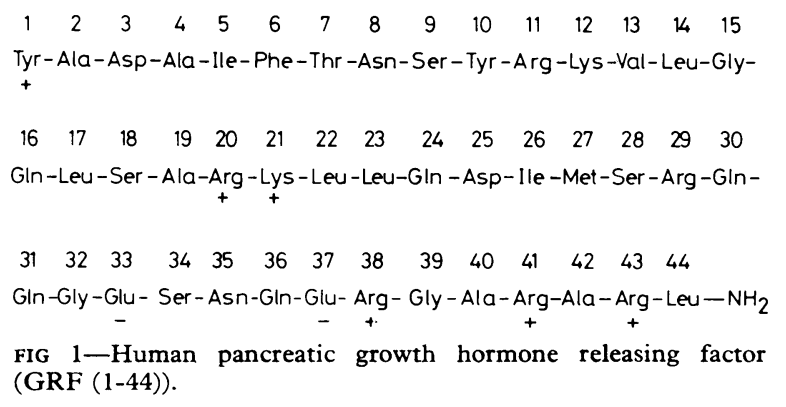

Introduction

Studies with hypothalamic extracts have for some time strongly suggested the existence of a substance capable of stimulating growth hormone secretion from the pituitary and so able to counterbalance the inhibitory effects of somatostatin. ${ }^{1-3}$ The technical difficulties of extracting and purifying the small quantities of active material present in the hypothalamus have so far prevented their full characterisation. Ectopic production of growth hormone releasing factors from non-pituitary tumours provides an exciting new source of these peptides. Although acromegaly is normally caused by excess secretion of growth hormone from a pituitary adenoma, there are now at least 11 reported cases of acromegaly presumed to be associated with ectopic secretion of growth hormone releasing factors from extrapituitary tumours, including pancreatic islet cell tumours and carcinoid tumours. ${ }^{4-6}$ Until recently these tumour related factors had been only partially characterised, ${ }^{4}$ but in the past year the extraction, purification, and sequencing of active growth hormone releasing peptides from two pancreatic tumours has been successfully carried out. ${ }^{7}$ Figure 1 shows 
the primary structure of the largest of these peptides (GRF (1-44)). This peptide and two smaller peptides, possibly degradation products (GRF (1-40) and GRF (1-37)), were present in one tumour, ${ }^{6}{ }^{8}$ while only the 40 amino acid form was isolated from another tumour. ${ }^{7}$ Analogues of these peptides have now been synthesised and it has been shown that the $N$-terminal 29 residues possess full growth hormone secretagogue activity in vitro. ${ }^{7}$ The relation of these peptides to the hypothalamic growth hormone releasing factors remains unknown. Comparison between GRF (1-40) and partially purified rat hypothalamic GRF, however, suggests a close similarity in structure and activity.

It has for a long time been apparent that insulin induced hypoglycaemia is a poor way of assessing pituitary somatotroph function. The stimulus itself is very variable, the test unpleasant, and medical supervision is required.

The effects of bolus doses of GRF (1-40) have recently been reported in man, where it is found specifically to stimulate growth hormone secretion with no effect on other anterior pituitary function. ${ }^{9}$ Nevertheless, no studies on the effects of the complete molecule GRF (1-44) on growth hormone secretion in man have been reported, nor has the influence of such peptides on secretion in growth hormone deficient or excess states, We have therefore examined these effects and report our findings.

\section{Subjects and methods}

Normal subjects-We studied 11 male volunteers (mean age 24 years). All were within $15 \%$ of ideal body weight and were in good health, had no personal or family history of endocrine disease, and were not receiving medication.

Patients with acromegaly comprised three men and three women aged 28-65 years (mean $50 \pm 5 \cdot 4$ ) and with a weight of $60-85 \mathrm{~kg}$ (mean $75 \pm 5 \cdot 6$ ). Table I outlines their clinical and biochemical features. All fulfilled the diagnostic criteria for acromegaly in that their basal non-stressed serum growth hormone values were greater than $10 \mathrm{mU} / \mathrm{l}$ and all showed either a paradoxical rise or a failure of suppression of growth hormone to $<5 \mathrm{mU} / \mathrm{l}$ after a $50 \mathrm{~g}$ oral glucose tolerance test. Three patients had been treated for acromegaly by yttrium-90 pituitary implantation and one by external irradiation bu they had not shown clinical or biochemical remission after treatment. Two further patients had previously been managed with bromocriptine but had developed side effects from therapeutic doses and so were not receiving this medication at the time of the study. Al six patients had enlarged pituitary fossas on $x$ ray examination, and computed tomography showed three of them to have partially empty sella (table I, cases 1, 2, and 4). Hypothalamic-pituitary function was assessed from basal hormonal concentrations and the responses to insulin induced hypoglycaemia (Actrapid insulin $0.3 \mathrm{U} / \mathrm{kg}$ ), to thyrotrophin releasing hormone $200 \mu \mathrm{g}$, and to luteinising hormone releasing hormone $100 \mu \mathrm{g}$.

Patients with impaired pituitary function-We studied six men and two women with impaired pituitary function. Their age range was 23-63 years (mean $41 \pm 5 \cdot 7$ ) and weight $50-82 \mathrm{~kg}$ (mean $64 \pm 4 \cdot 7$ ) Table II gives their clinical and biochemical features. Hypothalamicpituitary function was assessed as for the patients with acromegaly, from basal circulating hormone concentrations and their responses to insulin induced hypoglycaemia (Actrapid insulin $0 \cdot 15 \mathrm{U} / \mathrm{kg}$ ), thyrotrophin releasing hormone $(200 \mu \mathrm{g})$, and luteinising hormone releasing hormone $(100 \mu \mathrm{g})$. All patients had impaired growth hormone responses to insulin induced hypoglycaemia but other anterior pituitary dysfunction was variable.

Peptide-GRF (1-44) was synthesised by solid phase techniques

TABLE I-Clinical and biochemical features of patients with acromegaly

\begin{tabular}{|c|c|c|c|c|c|}
\hline $\begin{array}{l}\text { Case } \\
\text { No }\end{array}$ & $\begin{array}{l}\text { Age } \\
\text { and } \\
\text { sex }\end{array}$ & Aetiology and course & $\begin{array}{c}\text { Basal growth } \\
\text { hormone } \\
\text { concentration } \\
(\mathrm{mU} / 1)\end{array}$ & $\begin{array}{l}\text { Mean growth hormone } \\
\text { concentration during } 50 \mathrm{~g} \\
\text { oral glucose tolerance test } \\
(\mathrm{mU} / \mathrm{l})\end{array}$ & Hypothalamic-pituitary function \\
\hline 1 & $65 \mathrm{M}$ & Pituitary adenoma (partially empty sella) & 155 & $172(11 \%$ rise $)$ & Normal \\
\hline 2 & $49 M$ & $\begin{array}{l}\text { Pituitary adenoma (partially empty sella) } \\
\text { (untreated) }\end{array}$ & 29 & 21 ( $31 \%$ suppression) & $\begin{array}{l}\text { Impaired thyroid stimulating hormone response; other } \\
\text { responses normal }\end{array}$ \\
\hline $\begin{array}{l}3 \\
4\end{array}$ & $60 \mathrm{~F}$ & $\begin{array}{l}\text { Pituitary adenoma, "Y implant July } 1980 \\
\text { Pituitary adenoma (partially empty sella), } \\
\text { external irradiation (4000 rads) Nov }\end{array}$ & $\begin{array}{l}105 \\
188\end{array}$ & $\begin{array}{l}80(23 \% \text { suppression }) \\
178(5 \% \text { suppression })\end{array}$ & $\begin{array}{l}\text { Normal } \\
\text { Normal }\end{array}$ \\
\hline 5 & $28 \mathrm{M}$ & Pituitary adenoma, ${ }^{19} \mathrm{Y}$ implant March & 39 & $29(25 \%$ suppression $)$ & Prolactin value raised; other values normal \\
\hline 6 & $38 \mathrm{~F}$ & Pituitary adenoma, ${ }^{\circ} \mathrm{Y}$ implant Feb 1981 & 15 & $52(29 \%$ rise $)$ & Normal \\
\hline
\end{tabular}

TABLE II-Clinical and biochemical features of patients with impaired pituitary function

\begin{tabular}{|c|c|c|c|c|}
\hline Case No & Age and sex & Aetiology & Hypothalamic-pituitary function & Medication \\
\hline 1 & $40 M$ & $\begin{array}{l}\text { Probable hypothalmic sarcoid (positive Kveim } \\
\text { test result) }\end{array}$ & $\begin{array}{l}\text { Normal cortisol but impaired growth hormone } \\
\text { response to hypoglycaemia. Impaired thyroid } \\
\text { stimulating hormone and luteinising hormone- } \\
\text { follicle stimulating hormone responses. Normal } \\
\text { prolactin. Diabetes insipidus }\end{array}$ & DDAVP, testosterone \\
\hline 2 & $63 \mathrm{M}$ & Non-functioning adenoma, ${ }^{\circ} \mathrm{Y}$ implant 1981 & $\begin{array}{l}\text { Normal cortisol but impaired growth hormone } \\
\text { response to hypoglycaemia. No thyroid } \\
\text { stimulating hormone and impaired luteinising } \\
\text { hormone, and follicle stimulating hormone responses. } \\
\text { Normal prolactin }\end{array}$ & Thyroxine \\
\hline 3 & $46 M$ & $\begin{array}{l}\text { Craniopharyngioma. Hypophysectomy and } \\
\text { external pituitary irradiation } 1978\end{array}$ & $\begin{array}{l}\text { Normal cortisol but impaired growth hormone } \\
\text { response to hypoglycaemia. No thyroid stimulating } \\
\text { hormone or luteinising hormone-follicle } \\
\text { stimulating hormone responses. Normal prolactin }\end{array}$ & Thyroxine, testosterone \\
\hline 4 & $63 \mathrm{M}$ & $\begin{array}{l}\text { Post-traumatic pituitary failure (fracture of } \\
\text { temporal bone 1965) }\end{array}$ & $\begin{array}{l}\text { Impaired cortisol and growth hormone response to } \\
\text { hypoglycaemia. Impaired thyroid stimulating } \\
\text { hormone and luteinising hormone-follicle } \\
\text { stimulating hormone responses. Normal prolactin }\end{array}$ & Thyroxine, prednisolone \\
\hline 5 & $34 \mathrm{M}$ & Idiopathic panhypopituitarism & $\begin{array}{l}\text { Impaired cortisol and growth hormone response to } \\
\text { hypoglycaemia. Impaired thyroid stimulating } \\
\text { hormone and luteinising hormone, follicle } \\
\text { stimulating hormone responses. Normal prolactin }\end{array}$ & Thyroxine, prednisolone, testosterone \\
\hline 6 & $23 \mathrm{~F}$ & $\begin{array}{l}\text { Pituitary ablation for diabetic retinopathy }\left({ }^{\circ} \mathrm{Y}\right. \\
300000 \text { rads } 1976)\end{array}$ & $\begin{array}{l}\text { Normal cortisol, impaired thyroid stimulating } \\
\text { hormone and luteinising hormone, follicle } \\
\text { stimulating hormone responses }\end{array}$ & Insulin, thyroxine \\
\hline 7 & $31 \mathrm{M}$ & $\begin{array}{l}\text { Pituitary ablation for diabetic retinopathy ( } \\
600 \mathrm{Y}\end{array}$ & $\begin{array}{l}\text { Grossly impaired cortisol and growth hormone, } \\
\text { thyroid stimulating hormone, luteinising hormone, } \\
\text { and follicle stimulating hormone responses }\end{array}$ & Insulin, thyroxine, prednisolone \\
\hline 8 & $30 \mathrm{~F}$ & $\begin{array}{l}\text { Congenital hypoplasia of hypothalamus and } \\
\text { pituitary }\end{array}$ & $\begin{array}{l}\text { Normal cortisol but no growth hormone response to } \\
\text { hypoglycaemia. Normal thyroid stimulating hormone } \\
\text { but impaired luteinising hormone, follicle } \\
\text { stimulating hormone responses }\end{array}$ & \\
\hline
\end{tabular}


(Bachem). ${ }^{12}$ Before administration the aliquoted freeze dried peptide was dissolved in $0.25 \%$ human serum albumin (Elstree Laboratories, Herts) and made up to $10 \mathrm{ml}$ with isotonic saline.

\section{EXPERIMENTAL PROCEDURE AND ASSAYS}

This study was approved by the ethical committee of the Hammersmith Hospital and Royal Postgraduate Medical School. Each subject gave fully informed consent before joining the study.

Subjects reported to the metabolic unit at 9 am having fasted from midnight. Throughout the test period they lay supine in a relaxed environment. An indwelling intravenous cannula was placed in a forearm vein on their arrival and kept patent by citrated saline. No blood sampling was carried out for 30 minutes. Basal blood samples were then taken at 15 minute intervals over the subsequent 45 minutes. The peptide GRF (1-44) $100 \mu \mathrm{g}$ was given as a bolus intravenous injection over 30 seconds at time zero and blood samples taken at $2,5,8,12,15,20,30,40,50,60,90$, and 120 minutes. Pulse and blood pressure were measured at each sampling time and subjects asked to report any side effects.

Blood samples were taken into plain glass tubes, the serum being removed after centrifugation and stored at $-20^{\circ} \mathrm{C}$ for measurement of growth hormone and glucose concentrations.

All subjects received $100 \mu \mathrm{g}$ GRF (1-44). In addition, eight of the normal volunteers received on separate days doses of 10 and $30 \mu \mathrm{g}$ GFR (1-44), and six of these were also given $200 \mu \mathrm{g}$ on a further occasion.

Assays-Growth hormone was measured by a specific rapid radioimmunoassay procedure. ${ }^{10}$ The World Health Organisation's first international reference preparation for human growth hormone (MRC 66/217) was used as standard. All assays were carried out in duplicate and at multiple dilutions with parallelism between sample and standards. There was no cross reactivity between GRF (1-44) and growth hormone. Plasma glucose concentrations were measured by a glucose oxidase method using the Beckman glucose analyser (Beckman Instruments Inc, Fullerton, CA). ${ }^{11}$

\section{Results}

\section{NORMAL SUBJECTS}

Figure 2 illustrates the intersubject variability in the normal response of growth hormone to $100 \mu \mathrm{g}$ GRF (1-44). In all 11 subjects the onset of the response was rapid, in that there was a measurable rise in concentration within five minutes of the bolus injection of GRF (1-44). The peak value was reached between 12 and 50 minutes, occurring in nine subjects by 30 minutes, and varied between 13 and $67 \mathrm{mU} / \mathrm{l}$, with a mean peak value of $31 \cdot 8 \pm 4 \cdot 1 \mathrm{mU} / \mathrm{l}$ at 30 minutes. Values had fallen to $11 \mathrm{mU} / 1$ or below by 120 minutes.

Figure 3 shows the mean growth hormone responses to 10, 30, and $100 \mu \mathrm{g}$ GRF (1-44). The mean SEM peak growth hormone responses were $15 \cdot 7+6 \mathrm{mU} / 1,23 \cdot 9+5 \cdot 6 \mathrm{mU} / \mathrm{l}$, and $31 \cdot 8+4 \cdot 1 \mathrm{mU} / 1$ respectively; all occurred 15 to 20 minutes after the bolus injection of peptide. No further enhancement of the response occurred in any subject given $200 \mu \mathrm{g} \mathrm{GRF}$ (1-44). There was considerable intersubject variation in the magnitude of the response to a particular dose; however, the time course was similar in all subjects, with growth hormone returning to nearly basal values by 120 minutes.

\section{PATIENTS WITH ACROMEGALY}

Basal growth hormone values for the six patients with acromegaly fell between 13 and $160 \mathrm{mU} / \mathrm{l}$. Their responses to GRF (1-44) varied considerably; some patients (table I, cases 2, 3, and 5) had absolute rises in growth hormone values which were similar to those of normal subjects. In contrast, other patients (cases 1, 4, and 6) had a much greater and more prolonged release of growth hormone after GRF (1-44) compared with the normal group (fig 2). Comparison of these responses with the patients' responses to $50 \mathrm{~g}$ oral glucose showed that the three with the exaggerated responses to GRF (1-44) either had poor suppression or a paradoxical rise of growth hormone after oral glucose, while the three with the normal response to GRF had at least a $20 \%$, suppression of growth hormone after oral glucose.

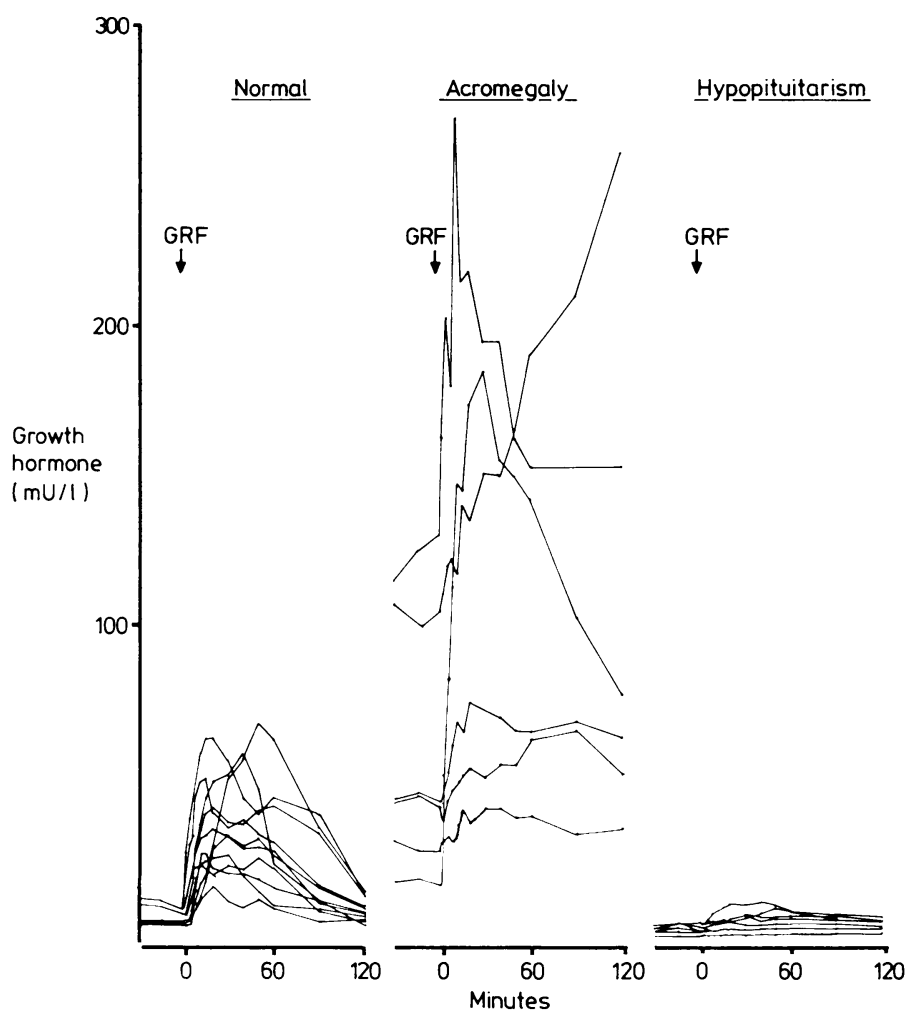

FIG 2-Growth hormone values in response to GRF (1-44) $100 \mu \mathrm{g}$ intravenously given at zero time in 11 normal volunteers, six patients with acromegaly, and eight patients with hypopituitarism.

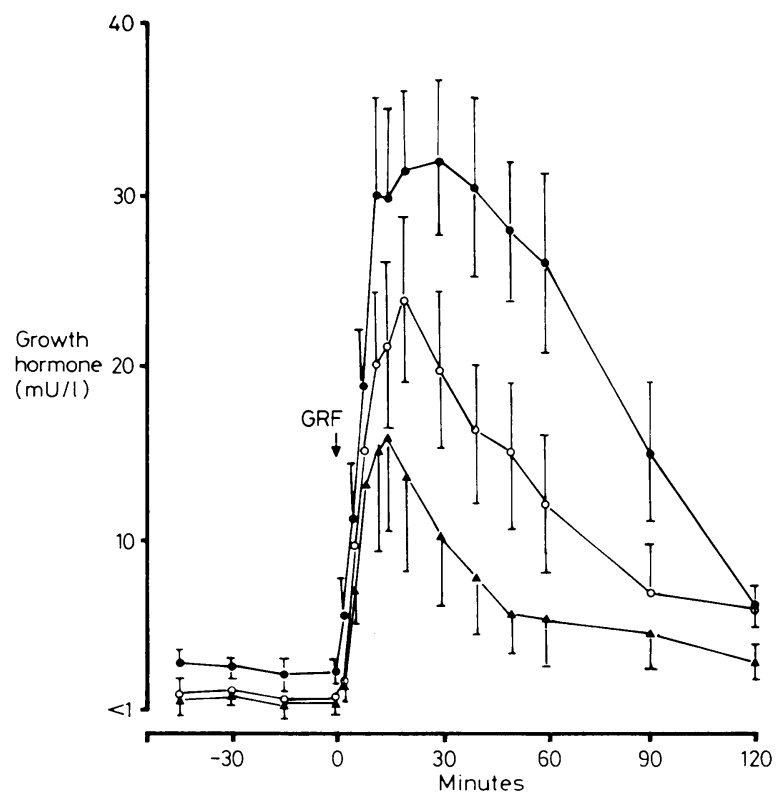

FIG 3-Mean serum growth hormone concentrations ( \pm SEM) in response to intravenous boluses of GRF (1-44) in normal volunteers $(\mathrm{n}=8) .(\Lambda=10 \mu \mathrm{g} . \mathrm{O}=30 \mu \mathrm{g} . \quad=100 \mu \mathrm{g}$.

\section{PATIENTS WITH IMPAIRED PITUITARY FUNCTION}

All patients with impaired pituitary function had basal growth hormone values below the lower limit of sensitivity of the assay ( $1 \mathrm{mU} / \mathrm{l})$. Two had no response to GRF (1-44) (table III, cases 4 and $7)$; the remainder had very much smaller responses compared with normal subjects, with peak growth hormone values between 1.2 and $7.3 \mathrm{mU} / 1$ occurring from 40 to 60 minutes after GRF (1-44), and in four of these patients the values had not returned to $<1 \mathrm{mU} / \mathrm{l}$ at 120 minutes (table III, cases $1,2,3$, and 5). 
Table III compares the growth hormone responses to GRF (1-44) and hypoglycaemia in each patient. In those who responded to both stimuli the response to GRF (1-44) was of more rapid onset and tended to be greater. Two patients (cases 1 and 5) showed no response to hypoglycaemia but had measurable rises of growth hormone after GRF, possibly indicating hypothalamic in addition to pituitary dysfunction in these patients. There was good correlation between the two tests in those patients who primarily had pituitary disease.

TABLE III-Patients with impaired pituitary function: growth hormone responses to insulin induced hypoglycaemia (Actrapid insulin $0.15 \mathrm{U} / \mathrm{kg}$ ) and GRF (1-44) $100 \mu \mathrm{g}$, both given as bolus intravenous injection at time zero. (See table II for diagnosis)

\begin{tabular}{|c|c|c|c|c|c|c|}
\hline \multirow{2}{*}{$\begin{array}{c}\text { Case } \\
\text { No }\end{array}$} & \multirow{2}{*}{ Test } & \multicolumn{5}{|c|}{ Growth hormone $(\mathrm{mU} / \mathrm{l})$ at various times $(\mathrm{min})$ after injection } \\
\hline & & 0 & 30 & 60 & 90 & 120 \\
\hline & $\{$ Hypo & $<1$ & $<1$ & $<1$ & $<1$ & $<1$ \\
\hline 1 & GRF & $<1$ & 6.8 & $4 \cdot 3$ & 1.9 & 1.1 \\
\hline 2 & $\{$ Нypo & $<1$ & $<1$ & $2 \cdot 4$ & 3.9 & $2 \cdot 7$ \\
\hline 2 & $G R F$ & $<1$ & 3.4 & 3.1 & $2 \cdot 2$ & $2 \cdot 1$ \\
\hline & $\{$ Нуро & $<1$ & $<1$ & $1 \cdot 1$ & $1 \cdot 1$ & $1 \cdot 8$ \\
\hline 3 & GRF & $<1$ & $2 \cdot 0$ & $1 \cdot 8$ & 1.6 & 1.4 \\
\hline 4 & Hypo & $<1$ & $<1$ & $<1$ & $<1$ & $<1$ \\
\hline 4 & GRF & $<1$ & $<1$ & $<1$ & $<1$ & $<1$ \\
\hline 5 & $\{$ Нуро & $<1$ & $<1$ & $<1$ & $<1$ & $1 \cdot 2$ \\
\hline 5 & GRF & $<1$ & $1 \cdot 7$ & $2 \cdot 6$ & $2 \cdot 6$ & $2 \cdot 0$ \\
\hline & Hypo & $<1$ & $<1$ & 1.5 & $1 \cdot 1$ & $<1$ \\
\hline 6 & $\mathrm{GRF}$ & $<1$ & 1.0 & $1 \cdot 0$ & $<1$ & $<1$ \\
\hline & Hypo & $<i$ & $<1$ & $<1$ & $<1$ & $<1$ \\
\hline 7 & GRF & $<1$ & $<1$ & $<1$ & $<1$ & $<1$ \\
\hline 8 & Hypo & $<1$ & $<1$ & $<1$ & $<1$ & $<1$ \\
\hline 0 & GRF & $<1$ & $1 \cdot 0$ & $1 \cdot 0$ & $<1$ & $<1$ \\
\hline
\end{tabular}

\section{SIDE EFFECTS}

None of the normal volunteers or patients with acromegaly or growth hormone deficiency showed any appreciable change in pulse or blood pressure. Similarly there was no change in blood glucose concentration (measured in all samples) in any subject, including the two diabetic patients. The only subjective effect reported was in one normal volunteer who noted transient warmth of his face immediately after the $100 \mu \mathrm{g}$ dose, which was more pronounced after $200 \mu \mathrm{g}$; and in the same subject flushing of the face occurred at the higher dose but not the lower and was of short duration.

\section{Discussion}

GRF (1-44) is one of a group of peptides recently isolated from a pancreatic tumour ${ }^{6}$ which potently and specifically stimulates growth hormone secretion in vitro ${ }^{3613}$ and in vivo in animals. ${ }^{14}{ }^{15}$ There is considerable evidence that this ectopic peptide resembles hypothalamic GRF in structure and function.?

A previous study has shown GRF (1-40) specifically to release growth hormone in man. ${ }^{9}$ The effects of the entire molecule (GRF (1-44)) on growth hormone release in man have not previously been investigated and are reported here both in health and disease. Interestingly comparison of the growth hormone rises suggests that they are roughly equipotent.

GRF (1-44) was found dose dependently to stimulate release of growth hormone in normal man. The response was rapid with the mean peak response occurring at 30 minutes, and the mean growth hormone concentration had returned almost to basal values by 120 minutes. Pulse rate and blood pressure were unaffected, and the only mild side effect was warmth of the face in one subject associated with facial flushing at the highest dose. There was considerable intersubject variation in the magnitude of response, which may reflect variability either in the pituitary's responsiveness to GRF or in the counterregulatory effects of the inhibitory peptide somatostatin, as has been reported in animals. ${ }^{15}$

The control subjects were considerably younger than the patients with acromegaly or hypopituitarism; however, the growth hormone concentration does not vary with age and therefore we think that it is valid to compare the responses.
The growth hormone response to GRF (1-44) in acromegaly is of considerable interest. Although the numbers were small $p$ the patients with pituitary adenomas secreting growth hormone fell within two groups as regards their response to GRF $(1-44) \frac{1}{2}$ One group of patients had an absolute rise in growth hormons values within the same range as normal subjects, and theses patients had shown at least a $20 \%$ suppression of growth hormone in response to glucose. In contrast, the other group had a very large rise in growth hormone values in response to. GRF (1-44), and these either showed only a small suppression or showed a paradoxical rise of growth hormone to glucose? An exaggerated response to GRF (1-44) therefore seems to: suggest more active disease.

GRF (1-44) was found to be at least as potent in releasing growth hormone as insulin hypoglycaemia in patients with known hypopituitarism. The growth hormone responses to GRF (1-44) and to insulin induced hypoglycaemia were indeed comparable in our eight patients, but the response to GRF was of more rapid onset, providing the basis for a shorter stimulation test. Possibly the response to GRF (1-44) allows a distinction between a hypothalamic and pituitary defect in that in the hypothetical former case the growth hormone response may ber normal. Growth hormone cell hypoplasia, secondary to failurę of GRF drive, might, however, confuse the response. Avoidin\& the dangers of hypoglycaemia together with the total lack of side effects of GRF appear to favour strongly the use of this. peptide instead of insulin as a routine growth hormone stimula 8 tion test. In addition, the time of the peak growth hormone response to GRF would fit well with the responses to the other releasing hormones thyrotrophin releasing hormone ando luteinising hormone releasing hormone. One would anticipate that the further addition of corticotrophin releasing facto would allow the insulin tolerance test to be totally superseded $\vec{r}$

Our studies on the effects of GRF (1-44) on secretion oto growth hormone in normal man and patients with hypopituitarism and acromegaly suggest that it will prove to be of considerable use in assessing growth hormone deficiency and the activity of acromegaly. A bolus dose of $100 \mu \mathrm{g}$ of GRF (1-44\$ appears suitable for this purpose with blood samples for estimaอ tion of growth hormone taken at 0,30 , and 60 minutes. The shorter duration of such a test apparently without side effects would have considerable advantage over the present insulin hypoglycaemia test.

We thank the Medical Research Council and British Diabetie Association for grant support.

\section{References}

${ }^{1}$ Harris GW. Neurocontrol of the pituitary gland. Physiol Rev 1948;28 $\underline{\underline{O}}$

2 $139-79$. by a hypothalamic extract in vitro. Endocrinology $1964 ; 74: 408-14$.

${ }^{3}$ Schally AN, Baba Y, Nair RMG, Bennett CD. The amino acid sequence of a peptide with growth hormone releasing activity isolated from porcine hypothalamus. F Biol Chem 1971 ;247:6647-63.

${ }^{4}$ Frohman LA, Szabo M, Berelowitz M, Stachura ME. Partial purification and characterisation of a peptide with growth hormone-releasinf activity from extrapituitary tumors in patients with acromegaly. Clin Invest 1980;65:43-54.

${ }_{5}^{5}$ Thorner MO, Perryman RL, Cronin MJ, et al. Somatotroph hyperplasia successful treatment of acromegaly by removal of a pancreatic isle tumor secreting a growth hormone-releasing factor. F Clin Invest 1982;70:965-77.

6 Guilleman R, Brazeau P, Bohlen PE, Esch F, Ling N, Wehrenberg wo Growth hormone-releasing factor from a human pancreatic tumo $\$$ that caused acromegaly. Science $1982 ; 218: 585-7$.

${ }^{7}$ Rivier J, Spiess J, Thorner M, Vale W. Characterisation of a growt hormone releasing factor from a human pancreatic islet tumoup hormone releasing facture $1983 ; \mathbf{3 0 0}: 276-8$.
Natus

${ }^{8}$ Esch FS, Bohlen P, Ling NC, et al. Characterisation of a 40 residů peptide from a human pancreatic tumor with growth hormone releasing activity. Biochem Biophys Res Commun 1982;109:152-8.

9 Thorner MO, Rivier J, Spiess J, et al. Human pancreatic growth hormono releasing factor selectively stimulates growth hormone secretion in man. Lancet 1983; : 24-8. 
${ }^{10}$ Adams EF, Brajkovich IE, Mashiter K. Growth hormone and prolactin secretion by dispersed cell cultures of human pituitary adenomas: long term effects of hydrocortisone, estradiol, insulin, $3^{\prime}, 5^{\prime}, 3^{\prime}$ triiodothyronine and thyroxine. 7 Clin Endocrinol Metab 1981;53:381-6.

1 Sterling RE, Nagao RR. Evaluation of the glucose analyser. Clin Chem $1969 ; 15: 801-2$.

12 Merrifield RB. Solid phase synthesis. Fournal of the American Chemistry Society 1963;85:2149-56.

13 Brazeau P, Ling N, Bohlen P, Esch F, Ying S, Guilleman R. Growth hormone releasing factor, somatocrinin, releases pituitary growth hormone in vitro. Proc Natl Acad Sci USA 1982;79:7909-13.
${ }^{14}$ Wehrenberg WB, Ling N, Brazeau P, et al. Somatocrinin, growth hormone releasing factor, stimulates secretion of growth hormone in anesthetized rats. Biochem Biophys Res Commun 1982;109:382-7.

${ }^{15}$ Brazeau P, Ling N, Esch F, Bahlen P, Mougin J, Guilleman R. Somatocrinin (growth hormone releasing factor) in vitro bioactivity; $\mathrm{Ca}^{++}$ involvement, cAMP mediated action and additivity of effect with PGE $^{2}$. Biochem Biophys Res Commun 1982;109:588-94.

\title{
Evidence for a hypothalamic disturbance in cyclical oedema
}

\author{
J B YOUNG， A M BROWNJOHN，C CHAPMAN， M R LEE
}

\begin{abstract}
Fourteen women with cyclical oedema and six healthy female controls were investigated by use of a test in which thyrotrophin releasing hormone and luteinising hormone releasing hormone were given. Significant differences in the responses of prolactin, luteinising hormone, and follicle stimulating hormone were observed in the patients.

These findings suggest that there may be a hitherto unrecognised hypothalamic defect in cyclical oedema that may account for some of the previously unexplained clinical features and lead to a more rational therapeutic approach in the management of the disorder.
\end{abstract}

\section{Introduction}

Idiopathic or cyclical oedema is a disorder almost exclusively of women, characterised by intermittent bouts of generalised swelling aggravated by standing. Other recognised causes of oedema must first be excluded, and the diagnosis then rests on the typical symptom complex and whether an excessive diurnal weight gain occurs. ${ }^{1-3}$ The cause of the condition is uncertain. Previous studies have suggested that women with cyclical oedema have chronic hypovolaemia and that standing induces a decrease in urine flow and urinary excretion of sodium, ${ }^{145}$ but the mechanism for this hypovolaemia is disputed.

Attention has been drawn to the emotional lability exhibited by women with cyclical oedema..$^{16-8}$ So prominent is this feature that Thorn suggested that it should form a part of the clinical symptom complex for establishing the diagnosis. ${ }^{3}$ The major depressive disorders are often associated with a disturbance of the hypothalamic-pituitary axis, ${ }^{9-12}$ and in view of the psychological and emotional problems that accompany cyclical oedema we carried out a study to investigate hypothalamic function by means of a combined thyrotrophin

Renal Unit, General Infirmary, Leeds LS1 3EX

J B YOUNG, MRCP, registrar

A M BROWNJOHN, MRCP, consultant physician

Department of Nuclear Medicine, General Infirmary

C CHAPMAN, PHD, principal biochemist

Department of Medicine, General Infirmary

M R LEE, FRCP, consultant physician

Correspondence to: Dr J B Young. releasing hormone and luteinising hormone releasing hormone test in 14 women with the disorder.

\section{Subjects and methods}

Women complaining of generalised swelling and with a documented diurnal weight gain in excess of $1.4 \mathrm{~kg}$ were considered to have cyclical oedema provided that other causes of oedema had been excluded by physical examination and biochemical investigation. We studied 14 patients (mean age $35 \pm$ SEM 3.0 years and mean weight $67+3.5 \mathrm{~kg}$ ) and six normal female volunteers (mean age $32 \pm 2.5$ years and mean weight $61.5 \pm 2.0 \mathrm{~kg}$ ). No subject in either group was taking an oral contraceptive pill, but most patients had previously received diuretics. Whenever possible diuretic treatment was slowly withdrawn so that at the time of the study eight patients had stopped taking diuretics a minimum of three months previously, three were receiving them, and three had never received them. Informed consent was obtained, and the study was approved by the hospital research ethics committee.

All subjects were studied during the preovulatory phase of the menstrual cycle as confirmed by plasma oestradiol and progesterone concentrations. The study was conducted by the same investigator with the subjects recumbent after an overnight stay in hospital. A light standard breakfast was given at 0800 and an intravenous cannula inserted at 0900 . At 1000 basal blood samples were taken for measurement of concentrations of oestradiol, progesterone, prolactin, testosterone, leuteinising hormone, follicle stimulating hormone, and thyroid stimulating hormone. Consecutive injections of $100 \mu \mathrm{g}$ luteinising hormone releasing hormone (Gonadorelin, Ayerst) and $200 \mu \mathrm{g}$ thyrotrophin releasing hormone (Roche) were then given and blood samples taken at $20,40,60,90,120$, and 150 minutes for estimation of plasma concentrations of prolactin, luteinising hormone, follicle stimulating hormone, and thyroid stimulating hormone by radioimmunoassay. Statistical analysis of the results was performed using Student's $t$ test for unpaired observations.

\section{Results}

Prolactin (table)-The mean prolactin concentrations in the patients were significantly greater than those in the controls at 20 and 40 minutes $(p<0.025)$ and at 60 and 90 minutes $(p<0.05)$. Basal prolactin concentrations were normal in the patients except in one with galactorrhoea, in whom they were 1165 and $1041 \mathrm{mU} / 1$ at 0 and 150 minutes, respectively.

Luteinising hormone (table)-The mean response of luteinising hormone was more pronounced in the patients than the controls; at $40,60,120$, and 150 minutes these differences were significant $(\mathrm{p}<0.05)$.

Follicle stimulating hormone (table) showed a significantly different response in the patients compared with the controls at 120 and 150 minutes $(\mathrm{p}<0.05)$.

Thyroid stimulating hormone-The mean response of thyroid stimulating hormone was not significantly different between the 